\title{
A Garrison in Time Saves Nine:
}

Frontier Administration and 'Drawing In' the Yafahan Orochen in Late Qing Heilongjiang

Loretta E. Kim

The University of Hong Kong

lekim@hku.hk

\begin{abstract}
In 1882 the Qing dynasty government established the Xing’an garrison in Heilongjiang to counteract the impact of Russian exploration and territorial expansion into the region. The Xing'an garrison was only operative for twelve years before closing down. What may seem to be an unmitigated failure of military and civil administrative planning was in fact a decisive attempt to contend with the challenges of governing borderland people rather than merely shoring up physical territorial limits. The Xing'an garrison arose out of the need to "draw in" the Yafahan Orochen population, one that had developed close relations with Russians through trade and social interaction. This article demonstrates that while building a garrison did not achieve the intended goal of strengthening control over the Yafahan Orochen, it was one of several measures the Qing employed to shape the human frontier in this critical borderland.
\end{abstract}

\section{Keywords}


Butha, Eight Banners, frontier administration, Heilongjiang, Orochen

\section{Introduction}

In 1882, the Heilongjiang general’s yamen began setting up a new garrison. This milestone was distinctive because 150 years had passed since the last two were established, which had brought the actual total of garrisons within Heilongjiang to six.. The new Xing'an garrison (Xing'an cheng 興安城) would not be the last one built before the end of the Qing dynasty (1644-1911) but it was notably short-lived, in operation for only twelve years before being dismantled. Its ephemeral existence was nevertheless significant because it was a solution and pre-emptive response to problems both real and anticipated immediately during its establishment and in several decades before and after. Its erection was moreover one of several strategies the Qing pursued to contend with the inherent instability of a physical border and the people living in the frontier zone comprised of territory adjoining both sides of the border. ${ }^{1}$

The border in question demarcated the northeastern and southeastern limits respectively of the Qing and Tsarist Russian (1547-1917) domains that had been the principal concerns of their diplomatic relations in the preceding three centuries. The two states clarified and revised their mutual understandings of this boundary between them through several cycles of military conflict, diplomatic negotiation, and legal resolution. But their common border held different if equally justifiable meanings for the two

\footnotetext{
${ }^{1}$ In this article, the term "borderland” refers to the physical land adjacent to a legal border, and "frontier" is the political-economic-social zone in which people in a borderland were active but which is not associated with a particular geographic space.
} 
empires. Expansion was the prime objective for the Tsarist Russian side. Acquiring more territory and subjects was a perpetual mission, occurring in varying forms over time. ${ }^{2}$ From open military conquest in the seventeenth century to the de facto claims on land and natural resources by civilian settlements in the nineteenth, Tsarist Russian governments attempted to expand their reach ever southward. Qing rulers, on the other hand, were primarily interested in maintaining a stable and secure border. For the most part, they did not mirror their Russian counterparts’ ambition by striving to adjust the border in a northward direction. ${ }^{3}$ Instead, they concentrated on defending the geographic and political limits of their domain as defined by successive treaties. These descriptions are not meant to imply that these conflicting visions of the border, as a line to be crossed and redrawn from the Russian perspective and as a firm physical and legal barrier delimiting sovereignty over land and people from the Qing view, should be compared or judged against each other. Rather than reaching subjective conclusions about Russian “aggression” or Chinese “passivity,” what matters more from both military and political standpoints is that these divergent approaches to managing the border generated continual tension between the two states and complicated other aspects of their relations such as trade and cultural exchange.

Ongoing contention over the border was problematic not only for inter-state relations but for the administration of adjacent territory. The border, despite all efforts to mark and fortify it, was not an absolute partition of space and society. People and goods

\footnotetext{
${ }^{2}$ See Brower and Lazzerini 1997, and Khodarkovsky 2004.

${ }^{3}$ This interpretation is more prevalent in common references to the Qing dynasty's commitment to maintaining the border, particularly in Chinese-language scholarship, rather than in explicit arguments that the Qing did not have any ambition to take over Siberia or Central Asia. The very fact that the Qing did not launch military campaigns in those parts of Russia may also speak for itself.
} 
moved from one side to another with and without official sanction. Borderland inhabitants forged economic and social ties that sometimes compromised their political identities as subjects of different imperial governments. They prioritized their livelihoods and kinship relations over laws and mechanisms of border control that dictated what their physical positions and communal identities should be. Therefore, the first principle of borderland administration was that regulating people's movements in both directions across a border was equally important. In other words, keeping people within one's territory was just as significant and difficult as keeping people out of it. ${ }^{4}$ Another concept especially salient to this study is that borderlands did not disappear with the establishment of borders, but could be pliable and therefore manipulated according to varying circumstances. As many scholars of both China and other regions have argued, frontiers were zones that transcended linear borders. Even the most powerful government, equipped with ample material and human resources, could manage the physical frontier of a borderland by marking it with symbols of its authority and inspecting it with surveillance technology. It could not, however, eradicate or even comprehensively regulate cultural and social frontiers, which were arenas of human interaction upon which no concrete spatial and political limits could be imposed. ${ }^{5}$

The plasticity of frontiers was normally a liability from a borderland administrator's perspective, but it proved to be useful for both sides in the mid to late nineteenth century when the official border between Siberia and Manchuria became subject to re-interpretation. Tsarist Russia pursued a second wave of interest in territorial expansion by sending expeditions to navigate Manchuria’s waterways, building

\footnotetext{
${ }^{4}$ Although now often taken for granted, this point has been paradigmatically articulated about erecting and maintaining China's Great Wall in Waldron 1990.

${ }^{5}$ Lattimore 1940.
} 
infrastructure such as bridges, and settling migrant populations on Manchurian soil. Diplomatic agreements such as the 1858 Treaty of Aigun and the 1860 Convention of Beijing formally substantiated Russian gains achieved by these strategies. In the wake of this multi-pronged advance, strengthening control over the actual border was not enough and was ultimately a losing battle. The Qing succeeded in Heilongjiang, the administrative region of Manchuria immediately adjoining the border with Siberia, in manipulating a human frontier consisting of a native tribal population known as the Yafahan Orochen (Yafahan Elunchun 雅發罕鄂(俄)倫春). ${ }^{6}$ The process of “drawing in” (shoulong收攏) these people occurred in multiple stages from 1855 to 1905 and consisted of measures to change their geographical position so that they would be less able and likely to interact with Russians and to channel their manpower into the regional defense force. ${ }^{7}$ I argue that these measures, including the establishment of the Xing'an garrison, were critical military strategies for two reasons. First, they were imperative defensive tactics, because the Yafahan Orochen lived in areas that were most vulnerable to Russian infiltration and occupation. Secondly, they largely pre-empted Yafahan Orochen conscription into the imperial Russian military or exploitation in extracting Manchuria’s natural resources. Moreover, this case study shows that while the Qing state literally lost

\footnotetext{
${ }^{6}$ The Orochen went by many names during and after the Qing, and "Orochen" is one of several English translations of the native term "Orcien” that was transliterated in multiple combinations of Chinese characters (俄爾吞 / 俄羅春 / 俄樂春 / 俄倫春 / 鄂倫春). Pinpointing the Orochen in Qing government documents is additionally difficult because certain Orochen sub-groups were identified as being non-Orochen because the people in question identified themselves by clan or place-based names.

${ }^{7}$ Italicized terms in parentheses are Chinese unless otherwise identified as "Ma." (Manchu) or "Ru." (Russian). In cases of two terms in different languages stated together, Chinese vocabulary will be marked as "Ch." A Manchu term will only be mentioned for a given concept if the Chinese term was derived from it.
} 
ground progressively in Manchuria during the nineteenth century, it invested considerable and fruitful effort in consolidating control over people like the Yafahan Orochen who determined the actual parameters of political authority. The value of such decisive actions can only be fully appreciated through the counterfactual supposition that they had not been taken, in which case Heilongjiang might have become Russian territory during the nineteenth century.

The decades-long process of “drawing in” the Yafahan Orochen was neither simple nor straightforward, as will be seen in this article. Increasing control over their activities posed many challenges to the imperial center and Heilongjiang officials. The Yafahan Orochen in turn resented the new constraints on their former autonomy and resisted various measures to ensure that they remained in body and soul within the bounds of the Qing state. Problems of guaranteeing their livelihood and preventing them from retreating to areas where they could avoid the state's surveillance compelled officials to devise and implement several different strategies. The first section will introduce the background of this case, describing how Heilongjiang was one of the Qing’s “special administrative regions,” whereas tribute and military organization were two means of harnessing the human frontier from the mid-seventeenth century onward. The second section will outline the circumstances in the nineteenth century that sparked official concerns about the Yafahan Orochen's physical position. The third part will discuss how military exercises and other techniques of periodic monitoring were inadequate, leading to the brief life of the Xing'an garrison described in the fourth section. The fifth and final part, followed by a separate conclusion, analyzes how the "drawing 
in” of the Yafahan Orochen was assessed within decades and nearly a full century after it occurred.

\section{Fit for Purpose Management of Borderlands}

Building a new garrison as a means of strengthening control over one indigenous population may seem like an extreme measure, especially considering the requisite physical, financial, and human resources. In Heilongjiang, however, this development was consonant with the overall strategy the Qing had honed to articulate its sovereignty in the region and derive maximum benefits from the area's enduring characteristic as a frontier where a diverse population existed and where the imperial state had near monopolistic control over natural resources. Quite unlike preceding regimes that attempted to manage frontiers through appeasement of peoples living in and around them through trade and gift-giving or the construction of physical structures to deter their movement, such as the Great Wall, the Qing pursued two general strategies to administer its peripheral zones. ${ }^{8}$

The long-standing political tradition of making peace with indigenous peoples by granting them economic and social autonomy was the Qing modus operandi on the southern and western frontiers until the mid-eighteenth century. ${ }^{9}$ While non-Han natives of the southern borderlands were obligated to display nominal obeisance to the ruling Chinese imperial state, they exercised considerable agency in distributing resources and

\footnotetext{
${ }^{8}$ Frontier peoples as "barbarians" (yi 夷) who needed to be pacified is a running theme in statecraft throughout China’s imperial age. See Barfield 1989 and Fiskesjö 1999.

${ }^{9}$ Giersch 2006 and Herman 2007.
} 
handling social relations within their groups according to customary law. Leaders of these populations solidified their power and influence by accepting imperial appointments and serving as civil and military officials. ${ }^{10}$ They managed tribute and tax collection as well as conscription of laborers for official projects in Yunnan, Guizhou, Guangxi, Sichuan, Gansu, Qinghai, and Tibet. Starting in the early eighteenth century, the Qing center pared down autonomy in a process known as gaitu guiliu改土歸流 (replacing indigenous officials with imperial bureaucrats), which converted many of the native political and social units to fit them into the standard administrative structure for the Chinese heartland. ${ }^{11}$

In its northern borderlands, the Qing center used militarization to assert its authority over the indigenous populations. ${ }^{12}$ It co-opted Mongol leaders through intermarrying and granting autonomy as awarded to southern indigenous elites, but also did so by organizing Mongol tribes into banners (qi 旗), which were military and administrative divisions that the Qing founding fathers had created to muster manpower in the sixteenth and seventeenth centuries. ${ }^{13}$ The "new frontier" of Xinjiang, decisively incorporated into the Qing domain during the mid-eighteenth century, would also be subject to military administration by a cadre of military officials leading troops brought in from other regions, unlike in Mongolia where bureaucrats largely governed their own groups. In Qing Manchuria, roughly equivalent to what is now known as Northeastern China, the highest officials were generals (jiangjun將軍) but were not only in charge of

\footnotetext{
${ }^{10}$ Gong 1992.

${ }^{11}$ See Wu 1988, 251-65.

${ }^{12}$ See Di Cosmo 1998.

${ }^{13}$ Legrand 1976, particularly pages 148-87, and Sanjdorj 1980.
} 
borderland defense but all matters of civil concern. Their ability to perform both military and civil functions was vital because the management of concrete territorial boundaries and the porous ones between "foreign" and "native” peoples was equally important.

Creating these conjoint positions was especially rational given the evolution of Manchuria as a political region. Cossacks conquering Manchuria in the name of the tsar gained the attention of the Shunzhi (r. 1644-1661) and Kangxi (r.1661-1722) emperors because of people rather than land. The early Qing state was already preoccupied with the customary business of establishing its position as the imperial government of China and faced numerous pressing threats from its own subjects, such as the leaders of the Three Feudatories, and from foreigners of a known quantity such as the Dzungars (Zhunga'er 準噶爾), both of which threatened its very ability to rule. The “Russians” (Luocha羅刹), as people coming from Siberia were labeled collectively, were comparatively small fry in the pool of enemies. Nevertheless, their exploration of the middle and lower reaches of the Amur River became increasingly worrisome. ${ }^{14}$ Early efforts to repel their incursions involved indigenous tribes that launched their own defensive campaigns, the Qing official troops (Eight Banners, Baqi八旗), and foreign allies such as the 1654-1658 Chosŏn “northern expeditions (Ko. Nasŏn chŏngbŏl 羅禪征伐).”15 Through these campaigns, Qing officials learned more about Russian tactics of demanding tribute (Ru. iasak) from Manchurian indigenes, a practice that was not only lucrative but also politically

\footnotetext{
${ }^{14}$ The Tsarist state started to gather intelligence about the wealth of resources in the Amur River region from 1636, the first year of Hong Taiji's reign as the Chongde emperor. It dispatched two expeditions to survey the area in 1636 and 1641. Subsequent missions in 1646 and 1653 were fully armed, covered more ground, and invaded villages of native populations such as the Dagur. ${ }^{15}$ For the most recent comprehensive analysis of these campaigns' impact on both Qing-Russian relations and Chosŏn military development, see Kang 2013.
} 
meaningful because paying tribute signified loyalty to the tsar. Some native populations initially agreed to tribute, interpreting it as a form of trade, while others resisted what they considered to be unreasonable or unfavorable demands. Groups that either refused or changed their minds after agreeing to tribute faced violent consequences. The Russians committed arson, rape, plundering, and murder to coerce and punish Manchurian indigenes, as in 1683 when a group of twenty indigenous huntsmen was lured into a house that was then set on fire, killing all of the victims. ${ }^{16}$

Similar incidents occurred with such frequency that the Qing court realized military action was insufficient to thwart Russian attempts to take over territory through political and economic conscription. In 1686, after Qing troops defeated and destroyed the Russian fort of Albazin, which had been built on the grounds of Yagsi (Yakesa 雅克 薩), a Dagur (Dawo’er 達呼爾 / 達斡爾) city, the Qing center finally convinced the Tsarist state to engage in diplomatic discussion rather than continuing their dispute through combat. Negotiations to end military confrontation led to the solution of delineating not only land but also people in the 1689 Treaty of Nerchinsk. Russian houses on the southern (Qing) side of the border had to be moved to the northern (Russian) one. Hunters could not cross the border to pursue game animals without permission. And

\footnotetext{
${ }^{16}$ KX22.09.09 (October 28, 1693). QSL-SZ 112:4b-6a. Note that texts will be cited in one of two ways, as fascicle and page $(\mathrm{X}: \mathrm{Y})$ if the document in question is organized according to traditional Chinese binding and pagination, and fascicle and page $(\mathrm{X} / \mathrm{Y})$ if it is printed in fascicles but the pagination is in the modern style, or continuous throughout a bound volume.
} 
perhaps most importantly, people had to accept their political identities as Russian or Qing subjects based on where they lived. ${ }^{17}$

The Treaty was a turning point in Qing-Russian relations but was at best one of many catalysts in the development of two institutions that had been set in motion earlier in Manchuria. The first is the tribute system, which was just like what the Tsarist Russian state attempted to impose upon Manchurians. Economic obligation and political identity were directly linked together through this institution. Tribute was not about actually paying respect to the emperor in person, as was the centerpiece of tribute offered by foreign missions to the Qing, but was the harvesting of natural resources based on a standard schedule and set quotas. This practice had started during the Later Jin (16161636), when Jurchen rulers demanded obeisance from neighboring tribes by receiving their leaders as tributaries and remunerating them with foodstuffs and other goods styled as “gifts” (Ch. wulin 烏綾 / 烏林, Ma. ulin). After the establishment of the Qing, tribute became compulsory for all Manchurian peoples, with punitive measures applied to groups refusing to participate.

The second method of cementing the natives' political loyalty was military conscription. This approach was important because instead of bringing in soldiers from outside, the Qing mustered manpower from the region to defend it. Qing officials organized indigenous peoples into military units and moved them around the region according to tactical needs. ${ }^{18}$ Some of these forces were eventually sent out to other

\footnotetext{
${ }^{17}$ This clause prevented people from changing their allegiance from one state to another at will, a practice that had caused many disputes about the extradition of individuals and groups for several decades before the Treaty.

${ }^{18}$ For the processes of directed migration and enrollment of Manchurian tribes into the Eight Banners, see Liu 1998. This strategy of employing "local talent” was manifested in various ways,
} 
places in the empire, whether for specific and finite campaigns, or to be permanently resettled, such as the Xibe (Xibo 錫伯) and Solon (Suolun 索倫) peoples in Xinjiang. The Qing even exploited the physical strength of Manchurian populations not formally employed as soldiers, and they performed menial labor such as fetching water and harvesting timber for the supervising offices. Regional authorities held month-long military training periods during the spring and autumn for a certain number of ablebodied, mature males chosen from these groups. These month-long camps also taught agricultural and husbandry skills that participants used for officially mandated and private economic activities.

In Heilongjiang, tribute and military service went hand in hand for most of Manchuria’s non-Manchu and non-Mongol populations. The dual obligation to fill the Qing's state coffers and ensure its security was most obvious in the functions of the Butha division of the Heilongjiang Eight Banners. ${ }^{19}$ Besides training and being prepared

such as "proficient archers and tiger-killers" being enrolled in firearm battalions during the Kangxi reign. See QSG 130/3863.

${ }^{19}$ The administration of the first Heilongjiang general Sabsu (Sabusu 薩布素) took over responsibility for the hunting tribes (Ch. buteha dasheng buluo 布特哈打牲部落, Ma. butha niyalma-i aiman) comprising the Butha banners, formerly under the jurisdiction of the Court for Colonial Dependencies (Ch. lifanyuan 理藩院, Ma. tulergi golo be dasara jurgan). The Butha banners consisted primarily of the Solon and Dagur peoples that had moved southward into the Nen River (Nen jiang 嫩江) area during the Shunzhi reign. The term "Butha” referred to their traditional occupations of hunting and fishing. In the first phase of organizing the Butha division, from 1684 to 1692, the Heilongjiang general assigned 2,340 troops into 39 Solon and Dagur companies, which were then distributed into the Eight Banners. These soldiers were deployed to the area garrisons and outside of Heilongjiang to participate in battles within the Chinese heartland as well as other borderlands. Later, during the Yongzheng reign, 6,661 able-bodied Butha men, including Dagur, Solon, and Heje (Hezhe 赫哲), were conscripted into 108 companies, each consisting of men sharing clan or tribal ties. The Butha banners had their own leadership hierarchy in which Manchu commandants and vice-commandants were initially appointed to train the forces, but who were gradually replaced with officials from these groups to 
to fight foreign enemies and assist in regional law enforcement, the Butha banners were also expected to hunt for commodities (mainly fur pelts) as a regular duty. Soldiers in the Butha banners also maintained their traditional livelihoods of hunting and fishing to feed their families since they did not have designated sources of income such as banner lands that could be cultivated or rented out to tenant farmers. This system, subject to periodic and situational adjustments, stabilized by the end of the Yongzheng reign (1722-1735) and functioned until nearly the end of the dynasty. The standard composition of the Butha banners from 1725 onward is given in Figure $1 .^{20}$

[Figure 1 here]

The Orochen were one of the populations in the Butha banners that the Later Jin and later the Qing co-opted into the Manchus' tribute and regional defense systems. The Nerchinsk border settlement divided them from their co-ethnics in Russian territory ( $\mathrm{Ru}$. Orochony). The Orochen were different from other Manchurian populations, however, because they were divided into two sub-groups. One was the Moringga (Moling'a 摩(墨) 凌阿), the Manchu term meaning mounted on horse, who were official troops that received monetary and material compensation accordingly. ${ }^{21}$ Like other bannermen, they

lead ethnically homogeneous units. Moreover, since these troops were charged with harvesting indigenous produce such as the aforementioned sable pelts, they worked together not only as combat and routine defense units but as members of hunting and gathering collectives and as agricultural work teams.

${ }^{20}$ QHWT 182:47a; QHTD 70:17a; QBTZ 35:17a; QSG 130/3867-68.

${ }^{21}$ Official [standing (jingzhi bing 經制兵), or standard (zhenggui bing 正規兵)] troops included the Eight Banners and Green Standard (lüying bing 綠營兵) forces. 
were organized into companies (Ch. niulu牛祿, Ma. niru), led by captains and lieutenants.

The Yafahan, the Manchu term meaning pedestrian or literally “on foot," were only responsible for meeting semi-annual quotas of sable pelt tribute, for which they earned cloth and other items that they could not acquire through their principal economic practices of hunting and fishing. ${ }^{22}$ These Orochen were organized into five routes, each supervised by Dagur or Solon banner officials known as anda who served three-year terms. ${ }^{23}$ Anda collected tribute items from the populations to which they were assigned and monitored their living conditions. Three of the routes centered around their eponymous rivers: the Ali route around the Ali River阿里河, the Dubukur route around the Dubukur River (Duobuku'er He 多布庫爾河), and the Tuo route around the Tuo River托河. ${ }^{24}$ The other two routes were also based on rivers, the Kumar (Kuma'er 庫瑪 爾) route around the Huma River (Huma'er He 呼瑪爾河) and its tributaries, the Kun 坤 河and Fabiela 法別拉河Rivers, and the Birar (Bila'er 畢拉爾) route encompassed the Xun 遜河, Zhan 站河, Wuyun 烏雲河 and Jiameng 嘉萌河 Rivers.

In the absence of a proverbial "smoking gun," or singular explanation straight from a government document about why the Orochen were divided into two groups, several hypotheses related to logistics may be brought to mind. The first is that the costs

\footnotetext{
${ }^{22}$ In certain documents the Manchu terms Moringga and Yafahan were replaced by the respective descriptions of their primary work animals, "horse-raising” and "deer-raising," as seen in figure 1. See QBTZ 35:17a-b, QCWT 271:27b and 294:54a, and QHTD 97:5b.

${ }^{23}$ Anda 安達 / 諳達 is a Manchu term meaning “close friend” or “guest.”

${ }^{24}$ Pinyin in parentheses will only be given for place names differing from English ones.
} 
of incorporating all of the Orochen into the military forces outweighed the benefits. The prime factor in this calculation was geography. In the early seventeenth century, the Orochen were active around the Amur River in what may be considered Northern Heilongjiang and on Sakhalin Island. The Qing government established garrisons in Southern Heilongjiang. Therefore, it was a matter of convenience to allow the Orochen at the region's literal edge to remain where they were. Collecting tribute from them was complicated, and the supervising officials had to take long journeys to and from the collection points. Conscripting them would therefore be even more challenging. Another possible reason why the Yafahan Orochen were not organized into military units is that they were more useful to the Qing government as civilian laborers. They did not receive income and rations, and because they could move freely, they could cover a wide range of hunting ground and procure more and better furs for tribute.

\section{Nineteenth-Century Blues}

Leaving the Yafahan Orochen out in the open for logistical convenience and economic advantage was tenable until the late eighteenth century. From the Yongzheng to Daoguang (1820-1850) reigns, citations about the five routes in government correspondence indicate that this management strategy was generally effective. ${ }^{25}$ Periodic problems did arise when tribute collection did not fulfill the quantitative or qualitative

\footnotetext{
${ }^{25}$ The major point of contention in Qing-Russian relations during this period was the scope of trade, not the positioning of the border. Disputes over the frequency of trading missions and what items should be traded had some indirect effect on borderland administrative operations such as where Russian traders should enter and exit Qing territory. For the most part, however, diplomatic agreements about the eastern border, such as the Treaty of Kiakhta and Treaty of Selenge, both ratified in 1727, were about making it clearer by adding more physical markers rather than adjusting its location.
} 
requirements of the designated quotas, as well as altercations between the Orochen and Russians and illegal trade with both Russians and Orochen from Russian territory. But in all, no major concerns arose about the viability of their livelihood or loyalty to the Qing. But as the number of security threats, whether posed by domestic “bandits” (daozei 盗賊) or by Russian soldiers and settlers increased in frequency and diversity, the Qing center sought extra manpower to deal with them. Such a strategy was especially critical after the 1858 Treaty of Aigun, by which the Russian empire gained a large part of the Amur River’s north bank and land south of the Outer Xing'an Range (wai Xing'anling 外興安 嶺), changing the shape of the inter-imperial border. Even what was irrefutably Qing territory were not entirely secure. Russian attempts to take over outposts (Ch. kalun 卡倫, Ma. kalun) and the increasing hardship of stopping illegal movements by Russian settlers back and forth across the border undermined the functionality of the Qing border defense system.

A combination of external and internal factors rocked what had been an otherwise steady trend of administrative institutions forming and operating effectively in Heilongjiang since the late seventeenth century. The Heilongjiang general's headquarters, originally set up in the “Heilongjiang garrison” at Aigun (Aihun 璦琿) in 1694, was moved to Mergen (Moergen 墨爾根) the following year, and then in 1699 to Qiqihar (Ma.

Čičigar, Ch. Qiqiha'er 齊齊哈爾), where it would stay until the general’s position was abolished in 1907. In 1732, the Heilongjiang command expanded with the establishment 
of two garrisons, Hulun Buir (Hulunbeier 呼倫貝爾) in present-day Inner Mongolia and

Hulan. The heads of all garrisons, whether garrison lieutenant generals, commandants, or military commandants (chengshou wei 城守衛), reported to the Heilongjiang general.

The number of troops, including officers, in Heilongjiang remained fairly stable, decreasing only slightly from 11,617 men stationed in six garrisons during the Qianlong reign (1735-1796) to 11,423 in the Jiaqing reign (1796-1820), a figure that remained more or less the same during the Daoguang and Xianfeng (1850-1861) reigns. ${ }^{26}$

The catalysts of change were both foreign and domestic. In the eighteenth century the Qing and Tsarist governments continued to fine tune their shared border, but the latter was mainly occupied with economic and social reforms within its domain as well as expansion into Central Asia. The Russian imperial center did make some overtures to increase its knowledge of Manchuria, such as asking for Qing approval to navigate the Amur in $1758 .{ }^{27}$ But it was only in the early nineteenth century that Manchuria became an explicit target of Russian territorial expansion when the more extensive policy of strengthening control over Siberia became imperative. The security of Heilongjiang was also jeopardized more indirectly by instability in other parts of the Qing empire, such as the eruption of the Taiping Rebellion in 1850 which compelled comprehensive reassignment of existing military resources.

Another set of factors that motivated the Qing government to evaluate its administration of Heilongjiang concerned specific problems arising in the region. Clauses spelling out punishments for illegal migrants, particularly fugitives, in Qing-Russian

\footnotetext{
${ }^{26}$ Chen 1992, 20-21.

${ }^{27}$ Forsyth 1994, 202. The reigning Qianlong emperor denied permission.
} 
treaties were insufficient to deter hunters, trappers, and convicts from traversing the border and indeed reflected the severity and frequency of these occurrences. ${ }^{28}$ As the border became more permeable, with individuals and groups moving back and forth across it, fortifying its defense became a greater priority for the Qing. Looking for more manpower, both in greater numbers and of higher ability, Heilongjiang officials reconsidered the Yafahan Orochen's status. ${ }^{29}$ They deemed the Yafahan Orochen suitable for military duties because they were physically strong and accustomed to harsh natural conditions and hard work. The Yafahan Orochen were also well-known for being excellent archers and marksmen. They consistently outperformed other Heilongjiang tributaries, including the Moringga Orochen, in submitting fur pelts of high quality. ${ }^{30}$

The Yafahan Orochen also incited concern because of the dsyfunctional tribute collection system. The anda who were supposed to be responsible for the timely collection of tribute from, and the distribution of supplies to, the five Yafahan routes often exploited their authority for personal gain. The Qing center was also concerned that as the natural supply of fur-bearing animals diminished, the Yafahan would avoid submitting tribute and flee to remote areas to evade the anda. Such a possibility had troubling political implications. If the Yafahan moved towards the border, they could cultivate closer relations with Russians, supplying them with furs, relying on them for

\footnotetext{
${ }^{28}$ Forsyth 1994, 203-4.

${ }^{29}$ Countering the Taiping Kingdom is often cited as a major impetus for military reform. See, for example, Shi 2003, 18.

${ }^{30}$ Tribute items such as pelts were assessed and sorted into multiple grades. Items that failed to meet the minimum criteria were rejected and did not count towards fulfillment of quotas set for each collection period. Existing data about tribute in memorials to the Qing center from the Heilongjiang general show that Yafahan Orochen tribute was often accepted in its entirety, or that $100 \%$ of submitted items passed the quality test, and frequently exceeded the minimum quota. Other tributaries' submissions were usually partially accepted and were judged lower in quality than those of the Yafahan Orochen.
} 
subsistence goods, and joining their armed forces either voluntarily or as conscripts. All of these actions could affect territorial claims if the Russian state insisted that the Yafahan were de facto Russian subjects.

\section{Old Wine in Old Bottles}

These problems came to a head right at the midpoint of the nineteenth century. The Xianfeng emperor, whose personal qualities have earned for him criticism for being "the weakest ruler the Qing had yet endured" ${ }^{31}$ was nevertheless on the throne when transformative crises were compelling his officials to develop tenable solutions. Yinglong 英隆, the Heilongjiang general when the Xianfeng emperor started his reign, did not generate any notable recommendations, but his immediate successor, I'ge 奕格, was comparatively proactive. Towards the end of his one-year tenure, I'ge memorialized about deferring the tribute from the five routes for one year so they could concentrate on defending the territory against the Russian encroachment he had reported several months before. ${ }^{32}$ I'ge rationalized this proposal by stressing the difficulty of moving troops into the endangered area from the four closest garrisons and that the Butha troops could not handle the additional burden of heightened security alone. He also worried that by going

\footnotetext{
${ }^{31}$ Rowe 2009, 201.

${ }^{32}$ XF (Xianfeng) 05.11.08 (December 16, 1855). QGJJ 406007075. All dates will be identified by both the lunar imperial and Gregorian calendars. The lunar imperial dates are stated in the following format: "Reign year. Lunar month. Lunar date.” An "r." in a lunar date indicates an intercalary month. Another note about documents is that some of the following documents were rendered in both Manchu and Chinese. Given that the author of this article has checked and determined that the contents of the versions in both languages are comparable, no particular citations of the versions in Manchu, which is the lesser-known language, will be made, since such reference would be most meaningful only in cases of substantive discrepancies with the Chinese editions.
} 
to the usual places for hunting sables, both the Yafahan and Moringga Orochen could get too close to the Russians crossing the border and going towards the Pacific Ocean in boats loaded with livestock, provisions, and military supplies. An Orochen lieutenant named Moergenei 莫爾格內 had already been coerced by Russians to provide navigational guidance, for which he was duly punished. The responding imperial edict debated the efficacy of this preemptory strategy but nevertheless agreed to defer the tribute so that the Orochens' livelihood would not be jeopardized. ${ }^{33}$

This temporary reprieve was not enough to mitigate, much less solve, the difficulties in keeping the Orochen away from the Russians and preserving law and order in their home area. Išan 奕山, I’ge’s successor, raised similar concerns two years later, asking for reinforcements to help existing personnel manage the Yafahan. ${ }^{34}$ Together with the Jilin general Jingchun 景淳, Išan played a key role in monitoring the Russian presence in the Amur River valley and receiving Russian emissaries. ${ }^{35}$ Based on his observations, he reasoned that since Russians in Heilongjiang were becoming more numerous and building settlements, they would be more likely to encounter the Orochen.

Since the Orochen were innately rough (fuxing cuguang 賦性粗獷) and did not understand moral principles (bu zhi lunli 不知倫理), they would inevitably incite conflicts with the Russians. Moreover, as the Orochen were in remote places, officials supervising them were on duty for long shifts, and so increasing their number was

${ }^{33}$ XF05.11.25 (January 2, 1856) XCSD, vol. 5, 445-56.

${ }^{34}$ XF07.11.22 (January 6, 1858). JMLZ 4424-031.

${ }^{35}$ XF07.07.10 (August 29, 1857) XCSD, vol. 7, 255, and XF07.08.21 (October 8, 1857) XCSD, vol. 7, 303. 
imperative to prevent disturbances. Since the Treaty of Aigun ceded Qing territory north of the Amur River to Russia in the same year, the Xianfeng court fulfilled Išan’s entreaty indirectly by approving the addition of 1000 cavalry troops to the Heilongjiang command. $^{36}$

As predicted by I'ge and Išan, Russian expansion into Heilongjiang led to evergreater troubles. A Russian contingent burned down an outpost in 1859 just at the end of Išan's tenure. His successor Tebčin 特普欽 repaired the wreckage and contemplated the greater implications of this arson case. ${ }^{37}$ Tebčin pleaded to the throne that as the Russians intended to occupy the area where the outpost was damaged, the native populations, particularly the Yafahan Orochen, Heje, and Fiyaka (Feiyaka 費雅卡), who were considered to be brave and fierce, could be the most useful forces to combat the Russians. By the same token, Tebčin stressed that they should not be left alone and thus vulnerable to Russian conscription for military and other functions. Therefore he recommended that they should be brought together to form militias. Tebčin felt that the Yafahan Orochen, who roamed around the Amur River basin to hunt for pelts, were especially talented marksmen and had a vigorous gait (bulü jiaojie 步履矯捷). He dispatched officials to investigate their situation, including two non-Orochen officers who were nevertheless familiar with the Orochen language. Based on accumulated knowledge, he believed that the Yafahan should be given grain rations so that their livelihood would not be adversely

\footnotetext{
${ }^{36}$ QSG 130/3868.

${ }^{37}$ This incident was cited in QGJJ 406011719, dated XF10.01.17 (February 8, 1860).
} 
affected and should be assigned to strategic passes after the next round of tribute collection. $^{38}$

Although placing the Orochen in strategic passes could alleviate the problem of Russians slipping into critical areas, Tebčin acknowledged that the Russians might in fact take advantage of the Yafahan leaving their respective home regions by infiltrating and also occupying those places. ${ }^{39}$ He recommended that the Yafahan return to their respective routes and move closer to garrisons and that all of their men be counted and evaluated for age and fitness. He provided basic figures regarding the number of men in each route as well as their usual and ideal positions. The Kumar route, with 1080 men, was in an area with a sizeable game population, but for the sake of the members' security and coordinated defense they were to be moved one hundred to two hundred li westward on the left bank of the Amur, and live and hunt within three to four hundred li of the Kumar River (Kuma'er he 庫瑪爾河) and the Humiken Mountain of the Inner Xing’an range (nei Xing'anling). The Birar route, consisting of three to four hundred men, hunted in Chele 車勒, which was close to the Russians. Therefore, they should be moved west eighty to ninety li towards the Zhan River and be active within three to four hundred li. The Tuo route, with 330 men, was also deemed vulnerable to the Russians. This route's men were to hunt within three to four hundred li of the Tuo River and Nuomin River 驽 敏河/諾敏河. The two smallest routes, the Ali with about 110 men and the Dubukur with about sixty men, were closest to the Mergen garrison. Their area of activity was to

\footnotetext{
${ }^{38}$ QGJJ 406011719.

${ }^{39}$ XF10.02.24 (March 16, 1860). QGJJ 406011932.
} 
be three hundred li around the Kuyur (Kuyu'er 庫玉爾河) and Ali Rivers. The imperial court approved all of these moves, which drew the Yafahan Orochen inward to the center of Heilongjiang.

Re-positioning the Orochen was important for maintaining tighter defense. As members of the human frontier with the Russians, however, they were both vulnerable and susceptible. At stake were not only their physical safety and the integrity of their formations as routes, but also their sustenance. Limiting their hunting to certain areas meant that their ability to meet the tribute quotas would be affected adversely. Since they relied on hunting for food, the Yafahan were especially in need of food assistance. The Dagur and Solon anda were generally responsible for distributing grain rations in exchange for the tribute pelts. In order to ensure an adequate supply, standard bannermen with extra rations were also permitted to sell them directly to the Orochen. However, since both the anda and ration-sellers could act in their own interest, they were to be strictly monitored and punished for committing even single offenses. ${ }^{40}$ From the state's perspective, the tribute and manpower for defense also had to be re-assessed in light of the information from a survey of households indicating that out of a total of about 1950 men, excluding the young, elderly, and disabled, there were only five to six hundred ablebodied men fit for hunting. Therefore, leaving them unsupervised meant that they might turn to the Russians for vital necessities. This concern became especially salient after the Treaty of Beijing was signed with Russia in November 1860. With the new border to be

\footnotetext{
${ }^{40}$ In a memorial dated XF10.03.04 (March 25, 1860) with content similar to the document from XF10.02.24 (March 16, 1860), Tebčin also mentioned that many Orochen were addicted to alcohol, which was leading them to flee when pressed to pay their debts for sustaining that habit, or to use clothing, guns, and horses to repay such liabilities. HJTS, 102.
} 
set at Suifen 綏芬 and along the Ussuri River (Wusuli jiang 烏蘇里江) in the spring of

the next year, Tebčin and the Jilin general Jingchun had to prepare accordingly. The arrangement of Orochen under the control of the Butha commandant seemed sustainable for both defense and the continuation of the sable pelt tribute according to existing requirements. $^{41}$

Tebčin's labor bore slow fruit. After strenuous efforts to re-set the HeilongjiangSiberia border in 1861, following the treaty, both signatory governments put that area on the back burner. It is worth noting that border adjustment work concentrated on geographic accuracy rather than the settlement of people. Documentary evidence suggests that officials were most absorbed in clarifying which river belonged to which empire. $^{42}$ But with the ascension of the Tongzhi emperor (1862-1874), the Qing center started to focus on other aspects of military and political reform, such as developing the Office of General Management (zongli yamen), one of the Xianfeng government's last achievements. The rise of leaders like Li Hongzhang and Zuo Zongtang during this period in turn fostered bolder measures to augment Qing military capacity. In this regard, the common thread linking the Xianfeng and Tongzhi reigns was the expansion of regional militias. ${ }^{43}$ The Tongzhi court increased the number of "trained troops" (lian jun 練軍) and provisions for such groups in Manchuria, as in other borderlands. But the major change that would eventually have a profound effect on Heilongjiang and the other areas of Manchuria during this period was the end of the ban on Han migration, enacted in 1860 for the section of the Amur River valley abutting the international border, and for

${ }^{41}$ XF10.11.03 (December 14, 1860). QGJJ 406013407.

${ }^{42}$ See Zhao 1970, 194-97.

${ }^{43}$ QSG 133/3959. 
other parts later in $1887 .{ }^{44}$ The gradual influx of Han migrants into Heilongjiang and other Manchurian locales was counterpoised by troops dispatched to other regions, such as 2000 Heilongjiang soldiers going to Uliyasutai in $1870 .{ }^{45}$ Until 1875 , however, officials raised comparatively few concerns about the Yafahan Orochen, perhaps because the Russian empire had larger fish to fry. Matsuzato Kimitaka has argued that the "long gestational period" between the acquisition of Priamur in 1860 and the establishment of the Priamur Governor-Generalship in 1884 was due to the Tsarist government taking a circumspect approach to administrative expansion. ${ }^{46}$ Even while all seemed quiet on its southeastern frontier, the Russian imperial center did sow seeds to spread its influence by moving the Chinese in the Ussuri River borderland back and forth across the border, where they received Russian official encouragement to settle down and marry native (Nanai and Korean) women. ${ }^{47}$

\section{Two Steps Forward, Three Steps Back}

In the first year of the Guangxu reign (1875-1908), the second step of controlling the movements and increasing the utility of the Orochen routes took shape. Since their work as prime tributaries was considered more important, the Heilongjiang general's yamen faced the dilemma of how to employ them as soldiers while making sure they had enough time to hunt. It ordered the Butha garrison lieutenant general cum commandant to check and report on the number of able-bodied men between 18 and 45 sui who could be

\footnotetext{
${ }^{44}$ See Gottschang and Lary 2000.

${ }^{45}$ QSG 137/4082.

${ }^{46}$ Matsuzato 2012, 365.

${ }^{47}$ Matsuzato 2012, 375.
} 
trained and dispatched to quell bandits in Jilin and Heilongjiang. ${ }^{48}$ The Heilongjiang general Fengšen 豐紳 went one step farther by proposing that five hundred of these men be chosen, given ammunition, and trained for forty days each year, starting on the first day of the third lunar month. ${ }^{49}$ They would receive cloth and grain rations during the training period, but for the rest of the year they should hunt normally and remain in their designated areas. Fengšen believed that the many "innate” traits of the Yafahan made them good combatants. Accustomed to hunting in rough mountainous terrain, they had robust constitutions, were excellent marksmen, and frightened the Russians. These ideas were hardly novel, but even as reiterations of what previous officials had concluded and articulated, they became important justifications for enacting the policy of "drawing in" the Yafahan.

In 1880 the Heilongjiang general Ding’an 定安 expanded the program to five hundred more individuals. One thousand participants were organized into units led by newly appointed company captains and lieutenants to conduct military drills. ${ }^{50}$ Each training session doubled as a civics seminar. Supervising officials lectured the participants about loyalty and admonished them not to cross the inter-imperial border. ${ }^{51}$ The training session also became a venue for the Heilongjiang general's yamen to assess the routes' performance in marksmanship and to distribute bolts of cloth to the participants.

${ }^{48}$ GX01.07.15 (August 15, 1875). HLJD 8-12.

${ }^{49}$ GX01.10.15 (November 12, 1875). GHZZ 2085-1.

${ }^{50}$ GX06.06.08 (July 14, 1880). GHJZ 190. Each of the routes gained a new corps of supervising officers with assignment to particular banners: Kumar to the Bordered Yellow, Birar to the Plain White, and the Dubukur, Ali, and Tuo to the Plain Yellow, as recommended by Ding'an on December 9, 1880 (GX06.11.08). JHLZ 7942-10.

${ }^{51}$ GX07.04.22 (May 19, 1881). GHJZ 213. 
These measures to rein in the routes while allowing them to maintain their livelihood and nomadic lifestyle proved to be problematic and inadequate to satisfy the ultimate objective of administering them more efficiently. Appointing capable officers to lead the routes was an ongoing challenge. Towards the end of his tenure, Ding' an worried that since many of these tribes were "similar to the Solon” but were unfamiliar with military institutional life, they would fare best under Solon commandants until there were enough co-ethnic officers to lead them. ${ }^{52}$ He also felt that it would also be in the state's best interest to assign the Kumar route to the Bordered Yellow Banner, the Birar route to the Plain White Banner, and the Dubukur, Tuo, and Ali routes to the Plain Yellow Banner. ${ }^{53}$ Whether Dagur or Solon officers should manage the routes, and whether banner officials or Yafahan chiefs should distribute the cloth, became debatable.

Taking a major step beyond corralling the Yafahan Orochen periodically, Ding'an's successor Wensioi recommended the establishment of a new garrison between the Heilongjiang and Mergen garrisons in 1881. In his proposal for the establishment of the Xing’an garrison, Wensioi 文緒 stressed that it was too hard for the Butha command to manage the Yafahan. Because there were no dedicated provisions in the Butha garrison's budget that would serve as material incentives for the Yafahan to follow orders, the administrative designation was hollow. They had become accustomed to roaming freely and were not responding well to the civilizing education to reform their behavior and curb their physical movement. Their disobedience had severe political implications

\footnotetext{
${ }^{52}$ GX07.06.01 (June 26, 1881). QSL-DZ 131: 884a-b. The Grand Council put forth a dissenting opinion in the following year, proposing that these troops be incorporated into existing units within the Butha banners, since their own supervising officers were treating them harshly. GX08.05.06 (June 21, 1882). QSL-DZ 146:63a-b.

${ }^{53}$ GX07.05.19 (June 15, 1881). GHJZ 216a.
} 
since they would run across the border to Russian territory to avoid Qing officials. Efforts to teach them how to farm and to give up their nomadic lifestyles for sedentary ones were unsuccessful.

Personnel problems also factored into Wensioi’s proposition. Route leaders bore the additional responsibility of distributing provisions to the Yafahan communities. The Heilongjiang general originally chose Dagur officers as anda for this task because they were the most efficient administrators. Dagur anda frequently reduced or withheld the provisions, taking them for their own profit, and then sought the protection of their coethnic vice-commandant superiors, who in turn were sheltered from punishment by the Dagur commandant. Wensioi, upon discovering this problem, recommended that the routes be turned over to the Solon commandant and his subordinates. In a memorial to the throne describing the Dagur chain of corruption, Wensioi stressed that the Yafahan could succumb to "temptation by foreigners" if the issue persisted ${ }^{54}$,The Guangxu court duly censured the Dagur officials and ordered the division of route leaders' duties. Manchu officials would supervise tribute collection and the prosecution of major crimes, while Solon officials would handle census-taking and general administration.

The Xing'an garrison, positioned to cover 1600 li of territory with an arsenal and a reserves storehouse (gongbei cang 公備倉), seven outposts, and a Guan Di temple, became the seventh garrison of Heilongjiang in $1882 .{ }^{55}$ The physical fort was built in Taiping Bay between the Aigun and Mergen garrisons and was central to the five routes’

\footnotetext{
${ }^{54}$ Written during an indeterminate month and day during the eighth year of the Guangxu reign. GCZZ 284-5.

${ }^{55}$ HJSL 2/32.
} 
locations. ${ }^{56}$ A commandant of garrison lieutenant general rank plus one Manchu commandant, one Orochen commandant, and ten vice-commandants (two Manchu and eight Orochen) assumed control over the five routes that remained separate from Moringga Orochen banner companies. The birth of the garrison was a panacea that would also yield long-term benefits for Heilongjiang's defense. The Yafahan were deemed valuable assets because they were already fluent in Chinese and Manchu as well as conversant in Russian and familiar with Russian culture. Their skill with weaponry was certainly a useful asset, given the Qing's need for trained troops. Secure employment would moreover dissuade the Yafahan from consorting with Russians, since it would free them from having to trade with the Russians for their livelihood.

Wensioi also proposed that the routes be reorganized and redistributed in the banners as part of the garrison formation process. ${ }^{57}$ The Kumar originally had three captains but needed five more (for a total of eight captains) and would be integrated into the left wing Bordered Yellow, Bordered White, Plain Blue, and Plain White banners. Similarly, the Birar, Ali, Tuo, and Dubukur routes formerly had a total of four captains, but now would have four more, for a total of eight, assigned to the right wing Bordered Blue, Bordered Red, Plain Red, and Plain Yellow banners. Each company captain would lead 58 or 59 men. ${ }^{58}$ Such an arrangement would facilitate a census of the Yafahan population every three years and the selection and drilling of one thousand men for one month during every spring and autumn. The tribute quota increased to match the training requirement. One thousand pelts would be expected each cycle. The Xing'an garrison

\footnotetext{
${ }^{56}$ Heilongjiang general to the Grand Council. GX08.09.01 (October 12, 1882). GHJZ 250.

${ }^{57}$ GX08.04.23 (June 8, 1882). QGJJ 122977.

${ }^{58}$ GX08.09.01 (October 12, 1882) GHJZ 250.
} 
would further be responsible for patrolling the mountains, performing customs collection, and preventing private sales of tribute furs.

Despite the rationality underpinning its design, the conscription policy did not facilitate or strengthen Qing authority over the Yafahan as much as intended. Reflecting on its eight years of operation, the Heilongjiang general Iktangga 依克唐阿 reported to the Grand Council in 1890 that many of the men came to the training sessions were already expert marksmen. ${ }^{59}$ They would, however, only come at their leisure rather than according to the schedule. Conscripts were often absent without leave and did not respond to orders when making an appearance. Officials tried to round up the Orochen, but the troops sent out to do so could not navigate the harsh terrain of Orochen habitats successfully. The next year, Iktangga wrote again to report that many of these talented recruits were no longer participating, having effectively deserted their units. ${ }^{60}$ Iktangga also submitted a critical report about the failure of Xing'an garrison officials to instill discipline into the Yafahan even after ten years, citing the dismal attendance rate at training sessions and the salaries languishing in the garrison vault uncollected because their would-be recipients did not show up. ${ }^{61}$ Iktangga also believed that the 100,000 silver taels dispensed in stipends over the ten years had been wasted because their dedication to the empire and the imperial army was still questionable. He proposed bolstering their allegiance through material incentives and encouraging them to adopt farming as a major occupation. Iktangga cited his own successful experience of visiting Orochen settlements and recruiting 200 strong men as part of his public pitch to translate

\footnotetext{
${ }^{59}$ GX 16.07.16 (1890.08.30) JHLZ 7942-5.

${ }^{60}$ GX17.03.21 (April 29, 1891). QHLD 1/104.

${ }^{61}$ GX17.03.21 (April 29, 1891). QHLD 1/104.
} 
their loyalty and esteem for the state into military service. ${ }^{62}$ He ordered another officer to train the draftees and help their dependents settle down in a nearby area. In his diplomatic mission, Iktangga also distributed money and rice to males not chosen for training as well as to women and children.

The issues and solutions that Iktangga put forth in his memorial were not original but were regularly mentioned in official documents about the Yafahan. Qing officials believed that the Yafahan were naive and needed to be controlled through appeasement. Instead of punishing them severely for their inconsistent participation in garrison duties or their disregard for their servitor status, supervising officers often assumed that the Yafahan were either irresponsible or simply unable to abide by regulations. To bring them into line, these officials recommended moral and cultural education, as would be applied to young children. If they learned how to conduct themselves properly and to espouse an agricultural, sedentary lifestyle in place of their transient, hunting one, the Yafahan would be more disciplined and become highly useful as soldiers. The Qing state was also concerned that if these people were not treated with care, they would contribute their talents to the Russians. Iktangga urged cautious moves to win over the Yafahan, stating that "if we pacify one more soldier's heart, we gain one more soldier's strength." 63

While his impressions just confirmed that old problems had yet to be solved, Iktangga made his mark by outlining a four-part strategy to reform Yafahan administration in $1894 .{ }^{64}$ He declared that after three years, “drawing in" was not yet effective and that further efforts and changes were necessary. Among the problems

${ }^{62}$ GX17.03.21 (April 29, 1891). QHLD 1/105.

${ }^{63}$ GX17.03.21 (April 29, 1891). QHLD 1/106.

${ }^{64}$ GX19.12.17 (January 23, 1894) QGJJ 130211 and QGJJ 130212. 
identified were that the Yafahan could not communicate well with other bannermen because of linguistic barriers, were accustomed to eating raw flesh of birds and beasts and wearing animal skins (shi rou yi pi 食肉衣皮), and living in the mountains; if they were forced into the banners, they might not like warm clothes and cooked food and would also be vulnerable to smallpox. All of these discomforts would likely make them recoil and go into hiding, and all efforts to draw them out of these remote areas would be for nought. Pragmatism was, therefore, essential. The previous regulations had to be readjusted according to actual circumstances and matters settled according to local conditions. The innate nature of the Yafahan should be a factor in creating mechanisms to monitor them. Moreover, capable officials had to be chosen, even if it meant selecting talent regardless of rank and ordinary promotion procedures (yong ren yi poge 用人宜破 格).

The tribute system, to which the Yafahan had long been the most productive contributors, also suffered with the establishment of the garrison. Iktangga asked for the tribute to be temporarily deferred for the Xing'an Orochen because of the hardship they faced in maintaining their livelihood while hunting in barren mountains. ${ }^{65}$ The Imperial Household Department official Aisin Gioro Fukun 愛新覺羅福錕 and others responded that given that the Butha system was established during Wensioi's time with 1000 troops receiving one tael and corporals two taels monthly in exchange for one pelt per year, they would not presumptuously change the regulation but would consider deferring it temporarily. They checked into the use and purpose of such pelts and found that they

${ }^{65}$ GX20.01.23 (February 28, 1894). QGJJ 130214. 
were for providing the emperor and empress dowager with clothing and handiwork at the empress dowager's disposal. Their ultimate decision was that the general should still try choosing enough pelts and continue paying the tribute, since stopping it would be difficult. $^{66}$

\section{History Lessons}

Iktangga's resolve to restructure the Xing'an garrison was not enough to sustain it. With his departure to lead troops in the first Sino-Japanese War, the Qiqihar garrison lieutenant general Zengqi 增祺 became the interim Heilongjiang general. He oversaw the dismantling of the Xing'an garrison and the dispersal of the routes to other garrisons. The Heilongjiang garrison lieutenant general took over the Kumar companies. Likewise, the Tuo companies merged into the Hulun Buir garrison and the Ali and Dubukur companies joined the Mergen garrison. In a rare case of bottom-up influence, the Birar route did not return to the Butha garrison; the commandant was elevated to garrison lieutenant general status but was eventually reassigned to the Heilongjiang (Aigun) garrison. The Heilongjiang general's yamen also implemented the new system of a regiment colonel leading each route. In November 1894, Zengqi ordered the trial dispatch of regiment colonels from all routes to go into the mountains and carry out measures to corral the Yafahan. $^{67}$

The Heilongjiang general's yamen distributed compensation to each garrison for incorporating a route, but maintenance fees were to be paid out of their stipends and

${ }^{66}$ GX20.02.07 (March 13, 1894). QGJJ 130501.

${ }^{67}$ GX20.10.12 (November 9, 1894). GHZZ 2088-2. 
additional benefits were discontinued or reduced, such as the allowances for medicine. ${ }^{68}$ New officers were also selected. Some former Orochen captains were not content with their displacements and refused to participate in the reorganization. Officials testified that regular Orochen troops were also not pleased about the prospect of having non-Orochen superiors, emphasizing that such officers were not familiar with the mountain terrain and did not understand Orochen culture. ${ }^{69}$ The Orochen did not want to check their traps under such leadership, hindering the fur collection process. Zengqi proposed a slower and more gradual transition than the original plan of immediately installing the non-Orochen officers. He notified all the garrisons taking in Orochen routes that the company captain seals would not be transferred from the incumbents to the new appointees until both Orochen officers and troops could be convinced to accept the change. The incumbent captains would continue to lead groups into the mountains to check traps until the new captains learned how to navigate the roads and became more familiar with Orochen social and cultural norms. ${ }^{70}$

Regaining the cooperation of dismissed Orochen officers was also critical. They were considered prime candidates for leading followers across the border or for otherwise fomenting unrest, which would exacerbate the bandit and Russian incursion crises in the region. Zengqi addressed a specific problem caused by the re-organization or elimination of the commandant and four vice-commandant positions for Orochen in the Xing'an garrison. Without these posts, Orochen officers could not be promoted beyond the level

\footnotetext{
${ }^{68}$ This financial proposal authored by the Grand Council received imperial approval on July 2, 1894 (GX20.05.29), before the formal dissolution of the Xing' an garrison. HFYB 35.

${ }^{69}$ Qiqihar garrison lieutenant general to various departments. GX21.05.20 (July 12, 1895). QHLD $2 / 20$.

${ }^{70}$ Qiqihar garrison lieutenant general to various departments. GX21.05.20 (July 12, 1895). QHLD 2/21.
} 
of company captain. Being limited in their career prospects could have dampened their enthusiasm and made them feel like they were being treated unfairly. Zengqi recommended that a new regiment colonel (xieling 協領) position be established so that all Orochen company captains could aspire to ascend the hierarchy. ${ }^{71}$

The appeal of the Yafahan as hardy and effective soldiers carried on after the reorganization process was considered complete. The Grand Council received a memorial from the Heilongjiang general's yamen asking for general permission to disband some of the Orochen companies and to transfer their members to other units because "they are familiar with mountain paths, are excellent marksmen, and are tough on deserters, bandits, and other criminals." ${ }^{72}$ The Heilongjiang general's yamen thought it would be more useful to have the skilled Orochen troops deployed among other units, perhaps serving as a backbone to them much as veteran non-commissioned officers would in a Western army, than to be concentrated in their own well-trained companies. When the commanding officer of the Heilongjiang mines wrote to the Heilongjiang general's yamen about the inefficiency of the mine guards in keeping workers from absconding or repelling Russian and Solon bandits, the Heilongjiang general decided that Yafahan troops would be fit replacements. Since they were familiar with the mountains, they could chase and apprehend fugitive workers. Their well-known proficiency in shooting would deter bandits, or at least they could successfully engage intruders in combat. ${ }^{73}$ The mines commander agreed with the plan to replace some of the guards with Yafahan

\footnotetext{
${ }^{71}$ Qiqihar garrison lieutenant general to various departments. GX21.05.20 (July 12, 1895). QHLD $2 / 22$.

${ }^{72}$ June 18, 1896 (GX22.05.08). QHLD 2/102.

${ }^{73}$ Heilongjiang general to Commanding officer of the mines. GX22.05.28 (July 8, 1896). QHLD 2/102-3.
} 
troops and asked for permission to work with the Aigun garrison lieutenant general about selecting potential candidates. The Heilongjiang general's response emphasized that only those Yafahan willing to work should go to the mines. He feared that those employed through coercion would become resentful and run away, going as far as Russian territory.

The dispersal of the Yafahan did not improve administrative conditions. Some problems were short-term and directly related to reform. The Heilongjiang general's yamen submitted an extension request in 1896 explicitly citing the division as the reason furs could not be collected on time. The troops were adjusting to their new garrisons during the hunting season, and once they were settled in it was no longer the right time to hunt. ${ }^{74}$ Other issues like corruption became endemic and ongoing. After settling stipends and other forms of compensation, the Heilongjiang general's yamen discovered severe accounting discrepancies in the Xing' an garrison rolls. While the garrison was in operation, only two hundred to six hundred men attended each of the annual training sessions. The garrison stocked one thousand bolts of cloth, enough for all expected participants, and the official roster indicated that more than nine hundred bolts were distributed each time. ${ }^{75}$ The Heilongjiang general's yamen launched an investigation in 1897 to determine which officials had appropriated the bolts that had not been given to training attendees. It also discovered that regiment colonels were collecting illegal fees for transporting livestock. The incumbent general Enje 恩澤 recommended giving administrative stipends to these officials so that the Orochen rank and file could keep more of their meager government-distributed provisions. ${ }^{76}$

\footnotetext{
${ }^{74}$ Heilongjiang general to the Grand Council. GX22.05.16 (June 26, 1896). GHJZ 506.

${ }^{75}$ Heilongjiang general to the Grand Council. GX22.12.06 (January 8, 1897). GHJZ 512.

${ }^{76}$ GX23.04.12 (May 13, 1897). QSL-DZ 404: 276a.
} 
Only in the final decade of Qing rule did the prolonged, multi-stage project of increasing control over the Yafahan seem to be successful. By 1899, incidentally the same year when the last Heilongjiang garrison at Tungken (Tongken 通肯) was

established, the "brought in" Yafahan were promptly and adequately submitting tribute. ${ }^{77}$ Before his final illness and death that year, Enje memorialized that all measures were effectual. ${ }^{78}$ Similarly, Cheng Dequan 程德全, the last Heilongjiang general, noted in January 1905 that according to Gulgu 固魯固, regiment colonel of the Tuo route, his charges had been effectively drawn in. ${ }^{79}$ At the end of that year, Cheng summarized the whole process, stressing that the principal reason the Heilongjiang general's yamen had to manage the five routes directly after a long period of Butha administration was their poor treatment by the anda. In further finger pointing, Cheng deemed the Xing'an garrison to be a failure because the commandants and sub-commandants had been incompetent. His criticism extended even to the funds distributed to the regiment colonels for the routes' sustenance, and the fact that when the Yafahan came out of the mountains, they pillaged and looted. It was important, he deduced, that the regiment colonels be compensated amply so that they would supervise their routes ably, particularly the Kumar and Birar that came into most contact with Russians. ${ }^{80}$

\footnotetext{
${ }^{77}$ GX25.08.20 (September 24, 1899). QGJJ 408004816.

${ }^{78}$ GX25.03.13 (April 22, 1899). JHLZ 7942-7.

${ }^{79}$ GX30.12.09 (January 14, 1905). CJSZ 273, quoting the report of the Hulun Buir garrison lieutenant general Isingga 依興阿.

${ }^{80}$ GX31.11.07 (December 3, 1905). CJSZ 880. Cheng also emphasized the importance of assigning more and better individuals as route officials in the following year. GX32.03.11 (April 4, 1906). CJSZ 1181-82.
} 
Cheng’s ambivalent assessment ultimately did not matter for long-term political planning because Heilongjiang underwent a full-scale reform starting in 1905 with the elimination of the Butha, Hulan, and Tungken (Tongken) garrisons, the last of the three established only six years prior. The Aigun, Mergen, and Hulun Buir garrisons would similarly be terminated and converted into new administrative units in 1908. The Heilongjiang command had maintained a relatively stable troop headcount, and finances during its existence while being subject to the general reductions and austerity measures throughout the Qing military system. ${ }^{81}$ But the Xing'an garrison, like other stopgap tactics, was unsustainable. Contemporaneous observers posed various reasons for its certain failure, including the shoddy physical edifice and the fact that the anda supervising the Yafahan Orochen were appropriating over fifty percent of the tribute pelts. ${ }^{82}$ Garrison officials were therefore already facing an uphill battle to earn the trust and cooperation of the Yafahan Orochen populations. That the regional authorities had already lost credibility in the eyes of the Orochen continued to be a running theme in criticisms of the garrison from the Republican period all the way to the present. Instead of drawing the Yafahan Orochen closer, the garrison literally made them hide in the woods. ${ }^{83}$ But besides being wary of Qing officials, the Yafahan Orochen may have had other reasons for refusing to comply with institutions like the Xing'an garrison. $\mathrm{Xu}$ Shichang 徐世昌, writing in the last official year of the Qing dynasty, recognized that the Yafahan Orochen needed commodities from Russia such as guns and pelts, and traded

\footnotetext{
${ }^{81}$ From 1684 to 1875, the total number of Heilongjiang personnel, including troops and officers, only dropped from 13,000 to 10,000 .

${ }^{82}$ HJSL $2 / 34$ and 3/50.

${ }^{83}$ Two of many examples are EZQG 14 and EZJS 47.
} 
actively with Russians in a ruble-based economy. ${ }^{84}$ Russianization was another compelling reason to "draw in” the Yafahan Orochen and, concurrently, an explanation why the Qing government encountered resistance from the target population. Orochen women and children wore Russian-style clothing and adopted Russian names. ${ }^{85} \mathrm{Xu}$ furthermore highlighted that the policy towards the Yafahan Orochen was not just about enhancing military defense but also counteracting their dependence on Russians, such as by establishing schools to combat their illiteracy. ${ }^{86}$

\section{Conclusion}

The Qing government faced both familiar and new circumstances in the nineteenth century when formulating policies towards Heilongjiang and the Yafahan Orochen. Quite unlike the seventeenth century, when Manchurian indigenes viewed people from Russia as fearsome strangers, contact for trade and other purposes was common by the nineteenth century. The Qing government maintained the paternalistic attitude of protecting the borderland subjects from Russian exploitation, but in reality it was concerned about the consequences of cooperative interaction between Manchurians and Russians. Drawing in the Yafahan Orochen was therefore partially a defensive measure, but it was also a critical strategy to stem potential ambiguity about where this population belonged, physically and politically. By re-organizing the Yafahan Orochen

\footnotetext{
${ }^{84}$ DSZL, Frontier Affairs (bianwu 邊務) - Hulun Buir section (Hulunbeier pian), 31/1427.

${ }^{85}$ DSZL, Frontier Affairs - Hulun Buir section, 31/1428.

${ }^{86}$ DSZL, Frontier Affairs (bianwu) - Xingdong section (Xingdong pian), 11/1363.
} 
and placing them under the control of garrison officials, the Qing asserted its jurisdiction over these people.

Conscripting the Yafahan Orochen also enabled the Qing state to mitigate its weaknesses in managing physical geography. Continuing to administer the Yafahan Orochen only through the tribute system would have meant that they would be roaming around along the border without regular and consistent checks. They could not only cause trouble by either helping or fighting the Russians, but could also render the land a potential hotspot. The Yafahan Orochen were a liability for being active in the very areas that the Russians eyed and eventually claimed. The posts of Nikolaevsk, built right above the Amur estuary in 1850, and Ust-Zeisk, established at the confluence of the Amur and Zeya rivers in 1856 (renamed Blagoveshchensk in 1858), along with the town of Khabarovsk, founded in 1860 on the middle Amur, were all near areas where the Yafahan Orochen sought items for tribute and their own sustenance. Moreover, as seen in the case of Russians stealing Orochen household property and horses near the Huma River as late as 1907 , co-existence perennially led to crime and other forms of conflict. ${ }^{87}$ Therefore, the imperial center may have reasoned that moving them southward towards the garrisons was the only viable way to keep the Yafahan Orochen in line in the face of progressive territorial attrition. ${ }^{88}$

\footnotetext{
${ }^{87}$ A Han Chinese businessman named Tan Bashan 探巴善 and two Orochen men, Zangušan 蒼 古善 and Imeče 依莫車, declared that they were witnesses to this incident of larceny. Interrogations were held in Jalinda village (Jalinda tun 扎林達屯) and Huma village (Huma tun 呼瑪爾屯), both in Russia, and the Russian garrison at Heihe 黑河. XT03.06.07 (July 2, 1911). HLJS 282.

${ }^{88}$ The Qing state was not entirely passive about maintaining sovereignty over its subjects affected by Russian official and informal annexation. The Treaty of Aigun's first article affirmed that the “Manchu inhabitants” (Manzhou ren 滿洲人) of land around the left bank of the Amur River
} 
Aside from its significance for Heilongjiang frontier administration, drawing in the Yafahan Orochen was also consonant with empire-wide trends in military strategy, such as tapping into new sources of manpower. The Yafahan Orochen were similar to ethnic Han militias in the Qing interior in that they had not previously served in an official military capacity but were organized to handle conflicts in their home region. However, unlike the Han militias, which the Qing elite hesitated to mobilize because they were not considered entirely trustworthy, ${ }^{89}$ there were no particular stances that the Yafahan Orochen should not be conscripted. The particular means applied to the Yafahan Orochen also reflected the differences among provinces and provincial-level regions, or the lack of unified methods for training soldiers prevalent in the 1860s through 1880s. Heilongjiang, which was one of the regions targeted during the second wave of training reforms from 1875 to 1883 drew, like other sub-areas of Manchuria, from Eight Banner forces rather than from militias or Green Standard troops. ${ }^{90}$ In that vein, the Yafahan Orochen were brought into the Eight Banners system rather than becoming members of a new military institution.

Rooting out persistent sources of discontent to improve the troops’ morale was another characteristic of the Yafahan Orochen case that is comparable with military reforms in other parts of Qing territory. Zeng Guofan prioritized increased remuneration in assembling the Xiang army from regional and village militias to quell the Taiping Kingdom. The monthly stipends were several times what Green Standard troops earned,

ceded to Russia would remain under Qing administration and could not be harassed by their Russian neighbors, who would presumably have been doing so on official orders.

${ }^{89}$ CBYW-XF 2700-1.

${ }^{90}$ The first phase was from 1866 to 1873 . For the provinces/regions involved in each of the two phases and differences in compensation, facilities, and equipment among these areas, see Shi 2000, 178-80. 
and were significantly higher than what the recruits could expect to earn as self-employed farmers or laborers. ${ }^{91}$ The Heilongjiang general's yamen tried to increase the morale and ensure the loyalty of the Yafahan Orochen by rooting out routine corruption that had diminished the compensation they received for submitting tributes and by offering them better opportunities for promotion to higher military ranks. Yet while parallels may be drawn with contemporaneous developments, the treatment of the Yafahan Orochen was also unlike other general patterns in the late Qing, such as pursuing technological reform. The human and material resources utilized for re-organizing the Yafahan Orochen could have been invested for other purposes such as re-arming soldiers with better weaponry and training them in warfare techniques that would have made them better able to fend off Russian movements. Strengthening existing forces or creating entirely new ones would both have been in line with the general trajectories of military modernization during the Xinzheng (new governance) reform period (1898-1912). ${ }^{92}$ But the determined efforts to organize the Yafahan Orochen into companies and assign them to garrisons are understandable, despite the attendant difficulties, because doing so was in line with the overall belief that it was better to have (official) troops rather than to employ (nonofficial) warriors. $^{93}$

Therefore, rather than signifying weakness or even desperation, employing forces like the Yafahan Orochen with accommodations for the fits and starts in their incorporation demonstrates that the Qing military system was still evolving as late as the nineteenth century. Although the Eight Banners had become a mature branch of the

\footnotetext{
${ }^{91}$ Shi 2003, 41.

${ }^{92}$ Zhao 2003, 103.

${ }^{93}$ TZ07.04.20 (May 12, 1868). QSL-MZ 229: 27a.
} 
central government by the mid-eighteenth century, ${ }^{94}$ perceptions of its subsequent "decline," 95 whether measured by diminished resources or unimpressive performance in battles with foreign and domestic enemies, may inordinately cloud comprehensive assessment of how the Qing center strove to maintain military strength in straitened circumstances. Returning to the particulars of the Manchurian borderland, at the turn of the twentieth century the Heilongjiang command had thirteen thousand troops. Not all were well trained, equipped, or even fed, but their officers tried to mold them into units fit for purpose. Dagui 達桂 and Cheng Dequan, the last two Heilongjiang generals, hesitated to organize more cavalry units than they were able to. They also tried to maximize the distribution and usage of the motley assortment of the old firearms at their disposal because there was not enough money to equip forces with new ones. ${ }^{96}$

With such fortitude, it is imaginable that the officials responsible for the Yafahan Orochen would have preferred their compliance with the measures that were at least theoretically of mutual benefit for the Qing state and the Yafahan Orochen, but the reality was that over a century of remote administration had established norms of control that resisted change. The Yafahan Orochen resented the burdens of military work imposed on them in addition to the taxing tribute requirement that was suspended and reinstated intermittently until 1911. The Qing center might have mustered them more efficiently if it had exempted them from tribute instead of forcing them to assume dual roles as

\footnotetext{
${ }^{94}$ This assessment is substantiated by the conventional pattern in studies of the Eight Banners to concentrate on its development from the Later Jin to the Qianlong reigns, as exemplified by Elliott 2001 and Ding 2003.

${ }^{95}$ Some scholars claim that some units were already performing poorly on the front lines of battle as early in the mid-seventeenth century, so the definition and appraisal of the Eight Banners' military fitness varies considerably. See Shi 2003, 38.

${ }^{96}$ See Zhao 2003, 104.
} 
producers and fighters. The multiple steps in re-organizing the Yafahan Orochen may also have been partially attributable to inadequate management capacity. As Ding Yizhuang has argued, this cause was not unique to this case but endemic in the northeastern command. Officials, whether deployed to Manchuria or chosen from local talent, were of relatively low quality, and common official practices were questionable during the Kangxi through Qianlong reigns, which may have established problematic standards for the rest of the command's history. ${ }^{97}$

In the grand sum of things, the subject of this case study was at best a partial success for the Qing government. Until 1911, officials dealt with Yafahan Orochen households and individuals slipping over the border and attempted to repatriate them before the Russian government claimed them as subjects. The abiding fear that even the Yafahan Orochen staying within Qing territory would cooperate with the Russians seems reasonable because trade between the two groups carried on well into the Republican period. ${ }^{98}$ Furthermore, the Yafahan Orochen did not become a solid corps of frontline border guards and combatants, despite the positive assessments of their physical strength and martial fitness. Even after they were assimilated fully into banner companies, they were still considered ancillary members of the official military forces. This is evident in official records such as the Draft History of the Qing (Qingshi gao 清史稿), compiled in 1927. While the Dagur, Solon, and other Manchurian indigenous groups were all mentioned in this text as groups incorporated into the Eight Banners, the "Orochen” were

\footnotetext{
${ }^{97}$ Ding 2003, 160-64.

${ }^{98}$ Social history surveys conducted in Orochen communities during the 1950s and 1960s contain much information about Russian anda who were trading partners throughout the late Qing and into the 1920s and 1930s. See, for example, EMGB 25.
} 
described as “local militias” (xiang bing 鄉兵). ${ }^{99}$ This reference is clearly about the Yafahan Orochen because the description of them includes the detail that they were led by their clan leaders, not by banner company captains. This distinguishing feature and the fact that the Orochen were cited in the same fascicle as ethnic Han militias suggest that even though every effort was made to change how they were administered, the Qing government retained some reservations about the Yafahan Orochen’s military status.

Despite these internal misgivings, the Qing imperial center achieved its ultimate goal of holding its political ground in physically contested territory. It correctly recognized how important the human frontier was in the game of wielding nominal and actual authority. In 1861, as Qing officials were contemplating how to position the Yafahan Orochen, Ernst G. Ravenstein, a German-British geographer, observed that in the Amur River region, “The Manchus and some amalgamated tribes of Tunguzians are all of them soldiers; and, besides this, some of the other tribes are incorporated into a kind of militia.” ${ }^{100}$ He noted the numbers of military forces in Heilongjiang and Jilin and compared them to the "militia," which at 54,000 men greatly dwarfed the 238 officers and 10,431 troops in Heilongjiang and 323 officers and 12,852 troops in Jilin. ${ }^{101}$ Although he did not mention them explicitly, the context of his description suggests that the "militia" referred to armed men who were not in the Eight Banners, such as the Yafahan Orochen. In Ravenstein’s view, however, their unofficial status made them no

\footnotetext{
${ }^{99}$ QSG 133/3949. For a comparison of various terms referring to local militias, see Wakeman 1975.

${ }^{100}$ Ravenstein 1861, 75. R.K.I. Quested, in her general survey of Sino-Russian relations, makes the similar observation that the Orochen were part of the small "Manchu forces" that remained in the Amur River area, bearing comparatively "primitive" weapons to hold down the fort in both literal and figurative senses against both domestic and foreign enemies of the Qing state. See Quested 1984, 17.

${ }^{101}$ Ravenstein 1861, 74.
} 
less valuable as fighting forces, or at the very least, they contributed to the perception that the Qing still maintained a formidable presence around the Amur. In this regard, Qing tenacity in solidifying control over the Yafahan Orochen was a fruitful investment. Although it was unable to extinguish the flame of Russian expansion into Manchuria, the Qing set the appropriate priority of strengthening its control over the region's people.

\section{References}

Primary Sources

CBYW-XF: Chouban yiwu shimo Xianfeng chao 籌辦夷務始末咸豐朝. Edited by

Gugong bowuyuan 故宮博物院. 1929-1930. Reprint, Beijing: Zhonghua shuju, 1979.

CJSZ: Cheng jiangjun shoujiang zougao 程將軍守江奏稿. Taipei: Wenhai chubanshe, 1968. 
DSZL: Dongsansheng zhenglüe 東三省政略. Compiled by Xu Shichang 徐世昌. 1911.

Reprint, Taipei: Wenhai chubanshe, 1965.

EZJS: Elunchunzu jianshi 鄂倫春族簡史. Huhhot: Nei Menggu renmin chubanshe, 1983.

EMGB: Elunchun zizhiqi Mukui Gaolu, Aihun xian Xinsheng cun he Xunke xian Xin E cun buchong diaocha baogao 鄂倫春自治旗木奎高魯愛輝縣新勝村和遜克縣新鄂村

補充調查報告. Huhhot: Nei Menggu shaoshu minzu shehui lishi diaocha zu and Nei Menggu lishi yanjiusuo, 1963.

EZQG: Elunchun zizhiqi gaikuang 鄂倫春自治旗概況. Huhhot: Nei Menggu renmin chubanshe, 1981.

GCZZ: Guangxu chao zhupi zouzhe 光緒朝硃批奏摺. Compiled by First Historical Archives of China. Beijing: Zhonghua shuju, 1996.

GHJZ: Guangxu chao Heilongjiang jiangjun zougao 光緒朝黑龍江將軍奏稿. Beijing:

Quanguo tushuguan wenxian suowei fuzhi zhongxin, 1993. 
GHZZ:Gong zhong Hanwen zhupi zouzhe 宮中漢文朱批奏摺. Held by First Historical

Archives of China, Beijing.

HJSL: Heilongjiang shulüe 黑龍江述略. Compiled by Xu Zongliang 徐宗亮 et al. 1891.

Reprint, Harbin: Heilongjiang renmin chubanshe, 1985.

HFYB:. Hulunbeier fu dutong yamen ce baozhi gao 呼倫貝爾副都統衙門冊報志稿.

Translated by Bian Changshun 邊長順 and Xu Zhanjiang 徐占江. Hailar: Hulunbeier Meng lishi yanjiuhui, 1986.

HJTS: Tebčin 特普欽. Heilongjiang jiangjun Tepuqin shiwen ji 黑龍江將軍特普欽詩文

集. Edited by Li Xingsheng 李興盛 and Sun Zhengjia 孫正甲. Tianjin: Tianjin

chubanshe, 1987.

HLJD: Heilongjiang jiangjun dang’an 黑龍江將軍檔案. Held by First Historical Archives of China, Beijing. 
HLJS: Heilongjiang shaoshu minzu 1903-1931 黑龍江少數民族 1903-1931. Harbin:

Heilongjiang Provincial Archives and Heilongjiang Institute for Research on Ethnic Minorities, 1985.

JHLZ: Junjichu Hanwen lufu zouzhe 軍機處漢文錄副奏摺. Held by First Historical Archives of China, Beijing.

JMLZ: Junjichu Manwen lufu zouzhe 軍機處錄副奏摺. Held by First Historical Archives of China, Beijing.

QBTZ: Qinding Baqi tongzhi 欽定八旗通志. Ortai 鄂爾泰, et.al., eds. 1796. Reprint, Changchun: Jilin wenshi chubanshe, 2002.

QSG: Qing shi gao 清史稿. Edited by Zhao Erxun 趙爾巽 et al. 1927. Reprint, Beijing: Zhonghua shuju, 1985.

QSL: Da Qing lichao shilu 大清歷朝實錄. Compiled by reign. Reprint, Beijing:

Zhonghua shuju, 1986.

SZ: Shengzu 聖祖 [Kangxi reign]

MZ: Muzong 穆宗 [Tongzhi reign] 
DZ: Dezong 德宗 [Guangxu reign]

QGJJ: Qingdai gong zhong dang'an zouzhe ji jun ji chu dang zhejian 清代宮中檔奏摺及

軍機處檔摺件. Held by National Palace Museum, Taipei.

QHLD: Qingdai Heilongjiang lishi dang'an xuanbian 清代黑龍江歷史檔案選編.

Compiled by Heilongjiang Academy of Social Sciences, Institute of History. 2 vols. Harbin: Heilongjiang renmin chubanshe, 1987.

QHWT: Qinding huangchao wenxian tongkao 欽定皇朝文獻通考. Edited by Zhang Tingyu 張廷玉 et al. 1785. Reprint, Taipei: Taiwan shangwu yinshu guan, 1984.

QHTD: Qinding huangchao tongdian 欽定皇朝通典. Edited by Xi Huang 嵇璜 et al.

1787. Reprint, Shanghai: Shanghai guji chubanshe, 1987.

Ravenstein, Ernst G. 1861. The Russians on the Amur: Its Discovery, Conquest, and Colonization, with a Description of the Country, its Inhabitants, Productions, and Commercial Capabilities; and Personal Accounts of Russian Travelers. London: Trübner and Company. 
XCSD: Xianfeng chao shangyu dang 咸豐朝上諭檔. Guilin: Guangxi shifan daxue

chubanshe, 1998.

Secondary Sources

Barfield, Thomas. 1989. The Perilous Frontier: Nomadic Empires and China 221 B.C. to $A D$ 1757. Cambridge, MA: Basil Blackwell.

Brower, Daniel R., and Edward J. Lazzerini, eds. 1997. Russia's Orient: Imperial Borderlands and Peoples, 1700-1917. Bloomington, IN: Indiana University Press.

Chen Feng 陳鋒. 1992. Qingdai junfei yanjiu 清代軍費研究. Wuhan: Wuhan daxue chubanshe.

Di Cosmo, Nicola. 1998. “Qing Colonial Administration in Inner Asia.” The International History Review 22.2 (1998), 287-309.

Ding Yizhuang 定宜莊. 2003. Qingdai baqi zhufang yanjiu 清代八旗駐防研究.

Shenyang: Liaoning minzu chubanshe.

Elliott, Mark C. 2001. The Manchu Way: The Eight Banners and Ethnic Identity in Late Imperial China. Stanford: Stanford University Press. 
Fiskesjö, Magnus. 1999. “On the 'Raw’ and ‘Cooked’ Barbarians of Imperial China.” Inner Asia 1.2, 139-68.

Forsyth, James. 1994. A History of the Peoples of Siberia: Russia's North Asian Colony, 1581-1990. Cambridge: Cambridge University Press.

Giersch, Charles Patterson. 2006. Asian Borderlands: The Transformation of Qing China’s Yunnan Frontier. Cambridge, MA: Harvard University Press.

Gong Yin 龔蔭. 1992. Zhongguo tusi zhidu 中國土司制度. Kunming: Yunnan minzu chubanshe.

Gottschang, Thomas, and Diana Lary. 2000. Swallows and Settlers: The Great Chinese Migration from North China to Manchuria. Ann Arbor, MI: University of Michigan Center for Chinese Studies.

Herman, John E. 2007. Amid the Clouds and Mist: China's Colonization of Guizhou, 1200-1700. Harvard East Asian Monographs. Cambridge, MA: Harvard University Press.

Kang, Hyeok Hweon. 2013. "Big Heads and Buddhist Demons: The Korean Musketry Revolution and the Northern Expeditions of 1654 and 1658.” Journal of Chinese Military History 2.2, 127-89. 
Khodarkovsky, Michael. 2004. Russia's Steppe Frontier: The Making of a Colonial Empire, 1500-1800. Bloomington, IN: Indiana University Press.

Lattimore, Owen. 1940. Inner Asian Frontiers of China. New York: American Geographical Society.

Legrand, Jacques. 1976. L'administration dans la domination Sino-Mandchoue en Mongolie Qalqa: version Mongol du Lifanyuan Zeli. Paris: Institute des haute études chinoises.

Liu Xiaomeng 劉小萌. 1998. Manzu de shehui yu shenghuo 滿族的社會與生活. Beijing:

Beijing tushuguan.

Matsuzato, Kimitaka. 2012. "The Creation of the Priamur Governor-Generalship in 1884 and the Reconfiguration of Asiatic Russia.” The Russian Review 71.3 (July), 365-90.

Quested, R. K. I. 1984. Sino-Russian Relations: A Short History. Sydney and Boston: G. Allen \& Unwin.

Rowe, William T. 2009. China's Last Empire: The Great Qing. Cambridge, MA: Belknap Press of Harvard University Press. 
Sanjdorj, M. 1980. Manchu Chinese Colonial Rule in Northern Mongolia. Trans.

Urgunge Onon. New York: St. Martin’s Press.

Shi Duqiao 施渡橋. 2000. Zhongguo jindai junshi sixiang shi 中國近代軍事思想史.

Beijing: Guofang daxue chubanshe.

-----. 2003. Wan Qing junshi biange yanjiu 晚清軍事變革研究. Beijing: Junshi kexue

chubanshe.

Wakeman, Frederic, Jr. 1975. “Localism and Loyalism during the Ch’ing Conquest of Kiangnan: the Tragedy of Chiang-yin.” In Conflict and Control in Late Imperial China, edited by Frederic Wakeman, Jr. and Carolyn Grant, 1-25. Berkeley, Los Angeles, and London: University of California Press.

Waldron, Arthur. 1990. The Great Wall: From History to Myth. Cambridge: Cambridge University Press.

Wu Yongzhang 吳永章. 1988. Zhongguo tusi zhidu yuanyuan yu fazhan shi 中國土司制

度淵源與發展史. Chengdu: Sichuan minzu chubanshe. 
Zhao Yuntian 趙雲田. 2003. “Qingmo xinzheng shiqi dongbei bianjiang de junshi gaige” 清末新政時期東北邊疆的軍事改革. Shehui kexue jikan 147, 103-7.

Zhao Zhongfu 趙中孚. 1970. Qingji Zhong-E Dong san sheng jiewu jiaoshe 清季中俄東 三省界務交涉. Taipei: Institute of Modern History, Academia Sinica. 